\title{
Inventory Optimization using ERP to reduce final product lead time, Inventory value an inbound logistics cost for MTO, FMCG Company
}

\author{
Palawatta IT $^{1}$ and Perrera HSC ${ }^{2}$
}

${ }^{1}$ Midas Safety Biyagama, Sri Lanka

${ }^{2}$ Sri Lanka Institute of Technology, Sri Lanka

\begin{abstract}
Many multinational companies have adopted ERP systems to make sure material is available on time and inventory levels are low. However most of the companies are unable to choose between the most suitable master data configuration such that common objectives are achieved. Objective of this project was to develop a master data configuration to optimize inventory in such a way that material availability for production is high and inbound logistics costs were low with very low inventory levels. To apply this methodology as a case study we selected MTO, FMCG Company which has been using SAP as its ERP system. Initially at two stages the master data configurations were changed and performance was monitored subsequently. ABC analysis was done to identify the top materials which will be in "A" category in terms of consumption value. After that different master data configurations were adopted at three stages for each of the selected materials and the performance was monitored accordingly. The basic criteria's for measuring performance were average inventory value, material availability, inbound logistics costs and consumption percentage vs purchases. Finally the best master data configuration was identified based on said performance measures. It was found that majority of the time EOQ theory is correct and it can be used for any FMCG, MTO business models. On the other hand, ROL theory is not practical to use in a FMCG, MTO business model if the demand variation is high. It was also found that MTO, FMCG company material master data should be planned based on SAP MRP planning and for regular items Safety stocks should be maintained based on past consumption and for irregular items safety stocks should not be kept to minimize inventory. This method can be adopted by any company to improve their material availability rate, inventory and reduce inbound logistics cost. The project resulted in 1.2 million USD reduction in inventory within a years' time, an inbound logistics were reduced by closer to 100000 USD and material availability rate was increased by closer to 20\% for an X company which was operating under FMCG, MTO environment. The project was successful because of the efficient material master data planning in SAP. Main limitation of the application is that if a regular item becomes obsolete the entire safety stock allocated for that particular item will be obsolete leading to inventory issues.
\end{abstract}

KEYWORDS: ERP Systems, Inventory, Inbound logistics cost, MTO, FMCG, SAP 


\section{INTRODUCTION}

Competition in industries has led to high inventory levels to reduce the final product lead time. High inventory levels result in high inventory holding costs plus high operating cycles which causes inefficiencies and obsolete inventories. Many companies have adopted ERP systems however they were unable to choose between master data configurations which are most appropriate for the given material groups which have led to high inventory levels and stock out situations. Investments that have been done in ERP systems have gone in vain because of inefficient usage of master data configurations. Sometimes there is a trade-off between savings made by bulk purchase cost benefit, inventory holding costs and logistics costs. Industries are suffering because it is difficult to identify the optimum solution in this kind of a situation.

There are theories to identify the economic order quantity (EOQ) and Reorder levels (ROL), even though these are adopted in companies the expected results have being not achieved. Some companies are obtaining high material cost savings from bulk purchases and low inbound logistics costs. However on the other hand when the world is moving towards JIT practices these companies will suffer from high inventory holding costs and obsolete inventory. On the other hand some companies using JIT inventory management concepts have finally ended up purchasing at high prices which has led to high Cost of Goods Sold (COGS) and to low Gross Profit (GP) levels. These companies are having continuous inflows of materials which has led to high inbound logistics costs which intern has led to financial losses.

\section{BACKGROUND}

Multinational companies are facing issues in terms of inventory, material availability and high logistics costs even though these companies have adopted ERP systems. As such, it is important to develop a proper master data methodology to optimize inventory and achieve high material availability and low logistics costs.

In order to develop this methodology a FMCG, MTO Company which has been using SAP as the company's ERP system was selected. However on time material availability plus proper inventory management was lacking in the company. The inbound logistics cost was also in higher side because of Air freight costs. High inventory days and low material availability was causing financial as well as non-financial issues for the organization. Low material availability caused delays in confirmed shipments which caused reduction in on time in full (OTIF) shipments. As a multinational organization this issue was to be solved on urgent basis.

Table 1 gives the total inventory breakdown on month of Jan - 2014. Table 2 gives the material availability as at Jan - 2014 before the beginning of production month.

Table 1. Total Inventory breakdown Jan-2014

\begin{tabular}{|l|r|}
\hline & Jan-2014 USD \\
\hline FG Stock & 385,408 \\
\hline SFG Stock & 370,745 \\
\hline Raw Material & $1,116,675$ \\
\hline Packing Material & 289,056 \\
\hline Yarn & 657,289 \\
\hline Chemical & 477,333 \\
\hline B Grade Stock & 76,762 \\
\hline Fabric & 247,019 \\
\hline Liner Stock & $1,093,679$ \\
\hline Spares \& Loose Tools & 22,434 \\
\hline Plant Maintenance Stock & 161,997 \\
\hline Total & $4,898,397$ \\
\hline
\end{tabular}

Table 2. Material availability Jan-2014

\begin{tabular}{|l|l|}
\hline Material description & $\begin{array}{l}\text { Percentage } \\
\text { availability }\end{array}$ \\
\hline Chemicals & $90 \%$ \\
\hline Yarn & $64 \%$ \\
\hline Liners & $56 \%$ \\
\hline Packing materials & $48 \%$ \\
\hline
\end{tabular}




\subsection{Inventory management}

The concept of inventory management was first initiated by F.N. Harris in 1915.It was a very widespread problem in various industries at that time. Inventory management refers to the process of managing the stocks of finished products, semi-finished products and raw materials by a firm (Saxena, 2009).Proper inventory management will cut down costs and improve cash flow and revenue. Low inventories will result in low interest charges in capital locked up. If a company has proper inventory management then it has answers to two questions; that is; when to order and how much to order. In particular, those are the two main inventory decisions. Inventory management enables managers to increase productivity of working capital by preventing blocking up of working capital and reducing material costs (BOSE, 2006).

Company strategic goals, Sales forecasting, Sales and operational planning and production and materials requirement planning should all be considered when identifying the correct inventory management model to be implemented (Saxena, 2009).

Efficient management of Inventory management system leads to efficient flow of materials to the production system that lead to effective use people and machines (Saxena, 2009).Vendor managed inventory could be considered as a technique for inventory management.

\subsection{Models of Inventory}

According to R. Panneerselvam, (2008) there are two main types of inventory models of which one is deterministic models and the other is probabilistic models. Following basic deterministic models can be identified.

1. Purchase model with instantaneous replenishment and without shortages.

2. Manufacturing model without shortages
3. Purchase model with instantaneous replenishment and with shortages.

4. Manufacturing model with shortages.

In practice, these models are not applicable. There are variations in demand during supplier lead time which is the time between placing an order to receiving an order. On the other hand there are delivery delays that are prevalent in practice. In order to meet the variation in demand during lead time, it is proposed to use a safety stock and in order to meet the delivery delays, it is proposed to use a reserve stock. Inventory model which covers all these aspect are given below. For the Q system where a fixed order quantity is ordered, the reorder level is calculated using the following equation.

When using the $\mathrm{Q}$ system, the following equation provides the basis to obtain ROL.

$\mathrm{ROL}=$ Demand during Lead Time (DLT) + Variation in demand during lead time (Safety Stock) +Average Demand during delivery delays (Reserve stocks) (R. Panneerselvam, 2008).

Demand during lead time $=$ demand rate $*$ lead time period (in days or months)

Safety Stock $=K$ (Multiplication factor based on service level $) * \sqrt{\text { Lead time }} *$ Standard deviation of demand (Assumption lead time is constant)

Reserve stock $=(D *$ Maximum Delay * Probability of maximum delay) / (Number of weeks per year)

\section{RESEARCH METHODOLOGY}

Based on the historical master data which was available until January 2014 of FMCG, MTO company, major issues faced by the company in terms of performance criteria's relating to logistics cost, inventory days and material availability were first identified. Second, 
performance criteria's were measured based on the changes done to material master data system on jan-2014.

Third, in Aug-2014, based on the new methodology, material master data system was updated and performance criteria's were again measured monthly and annually. Six performance measures, namely, Total inventory, material availability, inbound logistics cost, Inventory value of material "A " category, consumption against purchases and over three months inventory values were identified at all three stages in order to assess and compare the performance of the new methodology.

Major material groups of the FMCG, MTO Company were identified to initialize the sample sizes for analysis purposes. ABC analysis was used as a tool to initialize the sample sizes and identified the "A" category materials for each material group. The performance of " $A$ " category materials were identified along with the performance of total inventory before and after the application of the new methodology. The Six performance measures described above were used to monitor the performance.

\subsection{Application of the Methodology}

First in month of Jan-2014 the master data was reviewed and amended based on past consumption and lead-time. Majority of the materials were having ROL based material master data and very small portion was operating under MRP in SAP. Here for "A" materials the changes made were identified along with its average inventory value before and after the changes. The other measurement that was taken is the percentage of consumption against purchases. In month of Aug-2014 the performance were measured for " $A$ " materials as well as for the total inventory. Here, when measuring performance other than the total inventory value, logistics costs and material availability was also be measured.
In month of Aug-2014, based on the new master data methodology, changes for MRP type were done from ROL to MRP for some materials in SAP and material master data was reviewed and amended accordingly, safety stocks were also introduced. For regular items safety stocks were introduced and for irregular items no inventory was kept. Safety stock was usually maintained as 1 month consumption without adhering to safety stock calculation theory. For chemicals, MRP type was not changed and ROL based system was kept. After Aug-2014 change, the performance measures were used to measure the performance of Inventory, material availability and logistics cost.

In month of Sep-2015 material master data was reviewed again based on theories and practical knowledge and after that the performance was measured using the said performance measures. Finally considering all above scenarios the best material master data configuration was identified which reduced inventory value, logistics cost and increase material availability before production month beginning for FMCGMTO Company.

\section{RESULTS \& DISCUSSION}

Table 3. Performance measurement of Jan-2014 Material Master data change

\begin{tabular}{|l|l|l|l|}
\hline \multicolumn{1}{|c|}{} & \multicolumn{1}{|c|}{} & \multicolumn{1}{|c|}{} & \multicolumn{1}{|c|}{} \\
\hline $\begin{array}{l}\text { Total } \\
\text { inventory }\end{array}$ & $\begin{array}{l}4,821,640 \\
\text { USD }\end{array}$ & $\begin{array}{l}4,542,000 \\
\text { USD }\end{array}$ & $5.8 \%$ \\
\hline $\begin{array}{l}\text { Average } \\
\text { material } \\
\text { availability }\end{array}$ & $64.5 \%$ & $69.3 \%$ & $7.4 \%$ \\
\hline $\begin{array}{l}\text { Total } \\
\text { inbound } \\
\text { logistics cost }\end{array}$ & 45022 & 52962 & $-17.6 \%$ \\
\hline $\begin{array}{l}\text { Inventory } \\
\text { value of “A” } \\
\text { Material }\end{array}$ & $1,433,003$ & $1,469,574$ & $-2.5 \%$ \\
\hline
\end{tabular}




\begin{tabular}{|l|l|l|l|}
\hline $\begin{array}{l}\text { percentage } \\
\text { of } \\
\text { consumption } \\
\text { against } \\
\text { purchases }\end{array}$ & $\begin{array}{l}\text { Not } \\
\text { accounted } \\
\text { for Jan }\end{array}$ & $33 \%$ & $\begin{array}{l}\text { Comparison } \\
\text { impossible }\end{array}$ \\
\hline $\begin{array}{l}\text { Over } \\
\text { month } \\
\text { inventory }\end{array}$ & 1737635 & 1569000 & $9.7 \%$ \\
\hline
\end{tabular}

After Aug-2014 material master data was changed as mentioned above. Performance measures were compared as follows for Sep 2015.

Table 4. Performance Measures

\begin{tabular}{|l|l|l|l|}
\hline $\begin{array}{l}\text { Performance } \\
\text { measurement }\end{array}$ & $\begin{array}{l}\text { Aug- } \\
\text { 2014 }\end{array}$ & Sep-2015 & Achievement \\
\hline $\begin{array}{l}\text { Total } \\
\text { inventory }\end{array}$ & $\begin{array}{l}4542000 \\
\text { USD }\end{array}$ & $\begin{array}{l}3339000 \\
\text { USD }\end{array}$ & $26.5 \%$ \\
\hline $\begin{array}{l}\text { Average } \\
\text { material } \\
\text { availability }\end{array}$ & $69.3 \%$ & $89 \%$ & $28.4 \%$ \\
\hline $\begin{array}{l}\text { Total inbound } \\
\text { logistics cost }\end{array}$ & $\begin{array}{l}52962 \\
\text { USD }\end{array}$ & $\begin{array}{l}29558 \\
\text { USD }\end{array}$ & $44.2 \%$ \\
\hline $\begin{array}{l}\text { Inventory "A" } \\
\text { value of "A" } \\
\text { Material }\end{array}$ & $\begin{array}{l}1469574 \\
\text { USD }\end{array}$ & $\begin{array}{l}1216185 \\
\text { USD }\end{array}$ & $17.2 \%$ \\
\hline $\begin{array}{l}\text { percentage of } \\
\text { consumption } \\
\text { against } \\
\text { purchases }\end{array}$ & $33 \%$ & $83 \%$ & $151 \%$ \\
\hline $\begin{array}{l}\text { Over 3 month } \\
\text { inventory }\end{array}$ & $\begin{array}{l}1569000 \\
\text { USD }\end{array}$ & $\begin{array}{l}1096000 \\
\text { USD }\end{array}$ & $30.1 \%$ \\
\hline
\end{tabular}

When analyzing performance measures separately below comparison can be made.

\subsection{Total inventory}

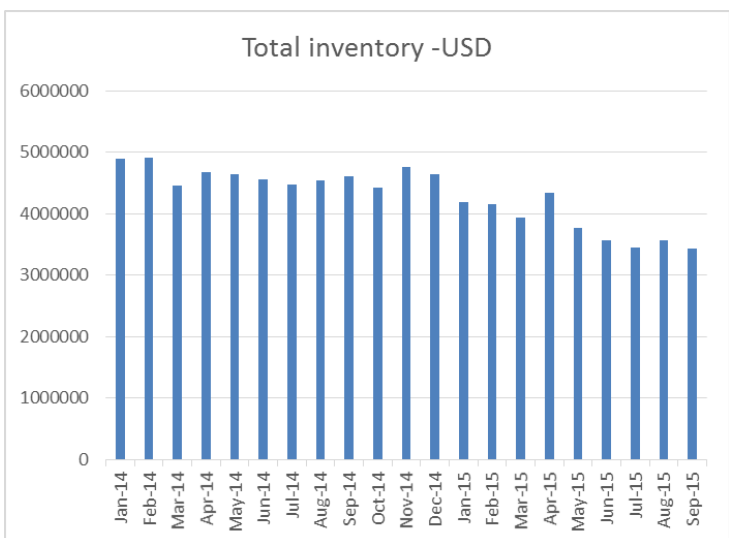

Figure 1. Total Inventory
Total inventory has being reduced drastically based on the material master data change made on month of Aug 2014. Thus it can be identified that the material master change was accurate and effective compared to the change done on month of Jan 2014.

\subsection{Average material availability-before production month beginning}

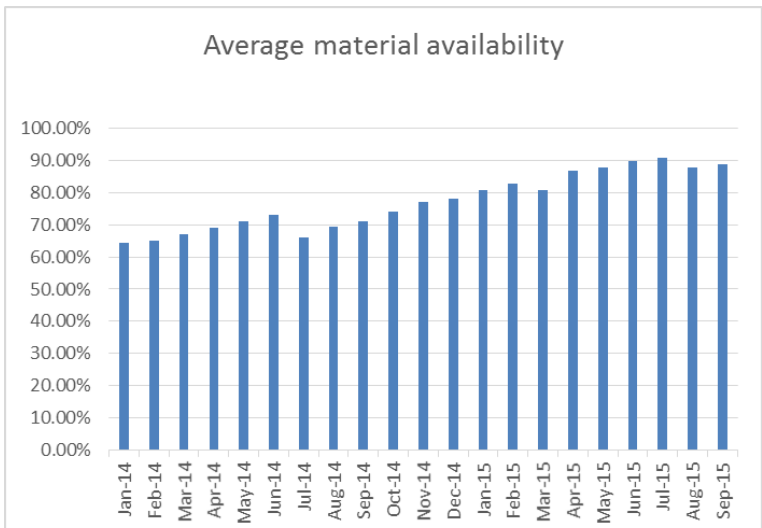

Figure 2. Average Material availability

The average material availability has increased gradually after material master data change which indicates that the material master change was accurate and effective compared to the change done on month of Jan 2014.

\subsection{Total inbound logistics cost}

\section{Total inbound logistics cost-USD}

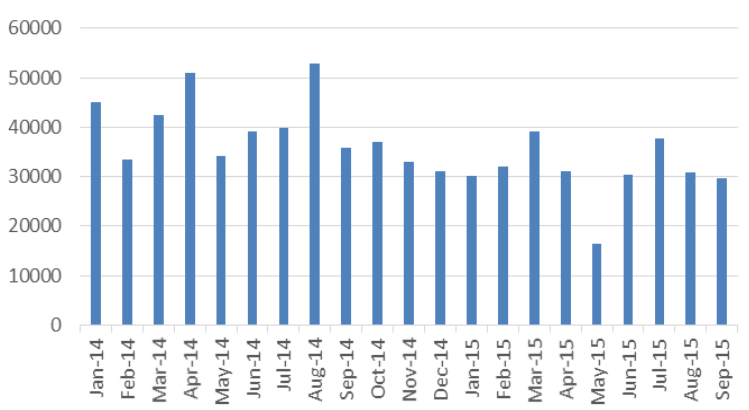

Figure 3. Total Inbound Logistics Cost

Total inbound logistics cost has reduced significantly due to reduction in Air freights and 
high material availability which is due to correct master data maintained in the system.

\subsection{Inventory value of Material " $A$ "}

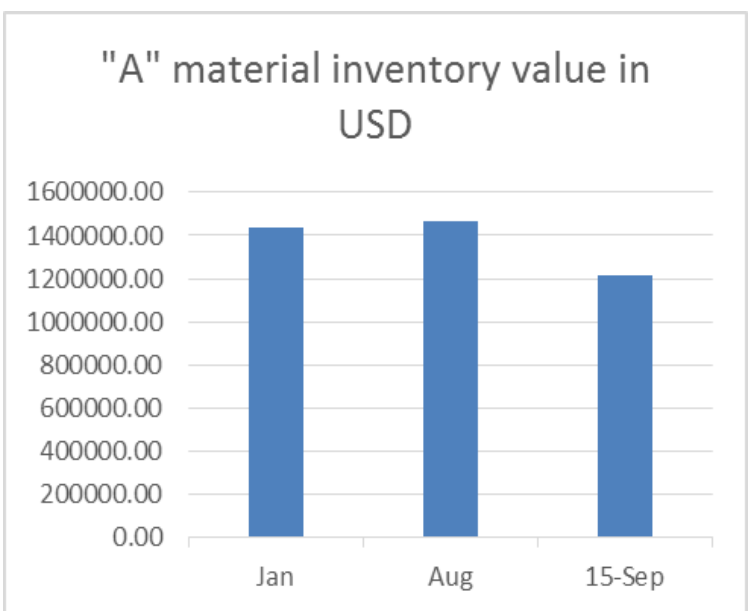

Figure 4. Inventory value of Material "A"

It can be seen clearly that based on the January master data change there was no improvement however we can see a significant improvement after the Aug month material master change which reduced " $A$ " material inventory value by a significant amount.

\subsection{Percentage of consumption against purchases}

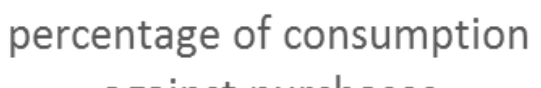
against purchases

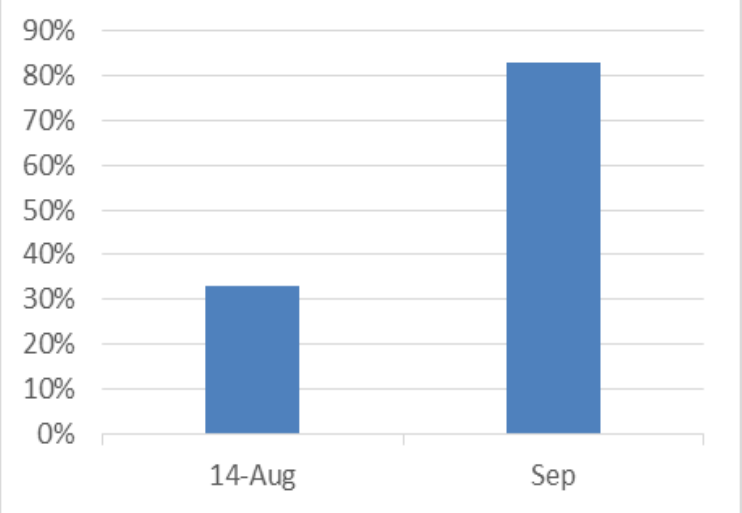

Figure 5. Percentage of Consumption against purchases
There is a high level improvement when considering percentage of consumption against purchases.50\% improvement is there in terms of material consumption which is because of correct material master data configuration. This gives a direct indication that purchasing is in line with consumption unlike previously where material was purchased without consumption.

\subsection{Over three month inventory}

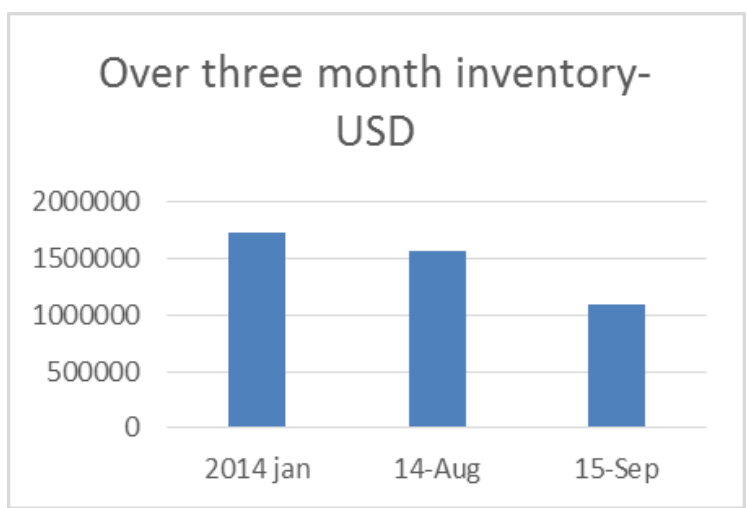

Figure 6. Over three month inventory

Over three month inventory has been reduced by approximately 500000 USD because of proper inventory control resulting from correct material master data.

\subsection{Theories of inventory}

When considering application of inventory theories like EOQ model and ROL model. Following can be derived when applying those theories to a business model. Here I have taken all the "A" materials in the factory and based on EOQ theories and ROL theories separately EOQ and ROL was calculated and compared with actual material master data. Following analysis can be derived from the same.

Based on the analysis it can be seen that $55 \%$ of the cases EOQ is practical however ROL theory is not practical as high inventory will result. $21 \%$ of the cases EOQ is practical as well as the ROL theory. Other than that it can be seen that most of the cases EOQ theory is practical but not the ROL theory. 


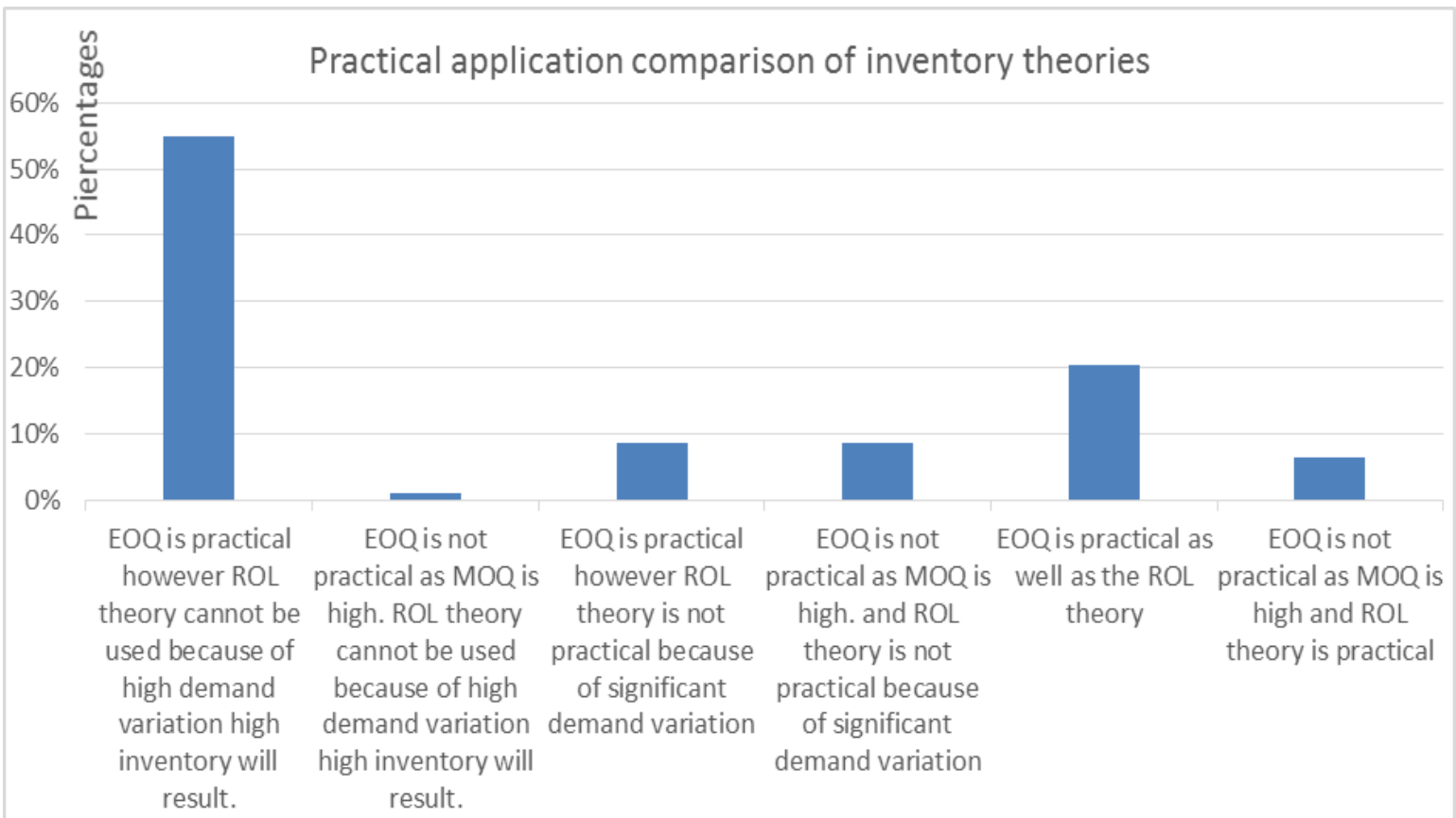

Figure 7. Practical application comparison of inventory theories

\section{CONCLUSIONS, RECOMMENDATION, LIMITATION AND FUTURE WORK}

\subsection{Conclusions}

The main result obtained by this project is the development of a material master data configuration for a MTO,FMCG company which reduced inventory, increase material availability before beginning of production month and reduce inbound logistics cost. The research project has allowed understanding of inventory management theories and whether it is practically possible to utilize these theories in actual working environment. It was derived that majority of the time EOQ theory is correct and it can be used for FMCG, MTO business models. Other than that it was derived that ROL theory is not practical to use in a FMCG, MTO business model if the demand variation is high.

Final conclusion that can be made from this research project is that for a MTO, FMCG company material master data should be planned based on SAP MRP planning except for chemicals which are procured and consumed in batches. For regular items Safety stocks should be maintained based on past consumption normally one month consumption taken for the higher side would be enough. For irregular items safety stocks should not be kept to minimize inventory.

The project resulted in 1.2 million USD reduction in inventory within a years' time, an inbound logistics were reduced by closer to 100000 USD and material availability rate was increased by closer to $20 \%$ for an X company which was operating under FMCG, MTO environment.

The project was successful because of the efficient material master data planning in SAP.

\subsection{Recommendations}

It is recommended to use above material master data configuration for any MTO, FMCG Company to obtain benefits in terms of inventory, logistics cost and material availability. 


\subsection{Limitations}

If a regular item becomes obsolete the entire safety stock allocated for that particular item will be obsolete leading to inventory issues.

\subsection{Future works}

To support the initiatives of this project it would be better if SAP calculates automatic safety stocks based on consumption .This will eliminate manually inserting safety stocks to SAP.

\section{ACKNOWLEDGEMENT}

This work has been successfully completed thanks to the support and advice of Professor Chandana Perera and Dr. Ganga Samarasekara.

\section{REFERENCES}

A MUCKSTADT J. Principals of inventory management. 1st ed. s.1.: Springer. 2010.

BANERJEE A \& KIM SL. An integrated JIT inventory model. International Journal of Operations \& Production Management. 1995; 15(9): 237-244.

BEHESHTI HM. A decision support system for improving performance of inventory management in a. International Journal of Productivity and Performance. 2010; 59(5): 452467.

BIGGART TB \& GARGEYA VB. Impact of JIT on inventory to sales ratios. Industrial Management \& Data Systems. 2002; 102(4): 197-202.

BOSE DC. Inventory Management. $1^{\text {st }}$ ed. New Delhi: Prentice hall of India Pvt (ltd). 2006.

BUSHUEV MA, GUIFFRIDA A \& KHAN MYJM. A review of inventory lot sizing review papers. Management Research Review. 2015; 38(3): 283-298.

CLAASSEN MJ, WEELE AJV \& RAAIJ EMV. Performance outcomes and success factors of. Emerald Insight. 2008; 13(6): 406-414.

FLORES BE \& WHYBARK DC. Multiple Criteria ABC Analysis. International Journal of Operations \& Production Management. 1986; 6(3): 38-46.

JACOBS FR. Operations and Supply Chain Management: The Core. $3^{\text {rd }}$ ed. s.l.: McGrawHill Higher Education. 2013.

JONSSON P \& MATTSSON SA. A longitudinal study of material planning applications in manufacturing companies. International Journal of Operations \& Production Management. 2006; 26(9): 971-995.

MERCADO EC. Hands-On Inventory Management. 1st ed. s.1.: CRC Press. 2007.

PARTOVI FY \& BURTON J. Using the Analytic Hierarchy Process for ABC Analysi. International Journal of Operations \& Production Management. 1993; 13(9): 29-44.

PIPLANI R \& FU Y. A coordination framework for supply chain inventory alignment. Journal of Manufacturing Technology Management. 2005; 16(6): 598-614.

PANNEERSELVAM R. Production and Operations Management. $2^{\text {nd }}$ ed. New Delhi: Prentice-Hall of India. 2008.

RAMASESH RV. A Logistics-based Inventory Model for JIT Procurement. International Journal of Operations \& Production Management. 1993; 13(6): 44-58.

SAXENA R. Inventory Management: Controlling in a Fluctuating Demand Environment. $1^{\text {st }}$ ed. New Delhi: Global India Publications. 2009. 